九州大学学術情報リポジトリ

Kyushu University Institutional Repository

\title{
Present Situation and Activation of Non- National Forests Management : Focused on Jeonbuk Province in Korea
}

Lee, Sang Hyun

Faculty of Forest Science, Chonbuk National University

Choi, Young Lak

Faculty of Forest Science, Chonbuk National University

Choi, Soo Im

Korea Forest Research Institute

Sato, Noriko

Laboratory of Forest Policy, Division of Forest Environment and Management Sciences,

Department of Forest and Forest Products Sciences, Faculty of Agriculture, Kyushu University

https://doi.org/10.5109/12876

出版情報: 九州大学大学院農学研究院紀要. 53 (2)，pp.575-584，2008-10-28. Faculty of Agriculture, Kyushu University

バージョン：

権利関係 : 


\title{
Present Situation and Activation of Non-National Forests Management - Focused on Jeonbuk Province in Korea -
}

\author{
Sang Hyun $\mathrm{LEE}^{1 *}$, Young Lak $\mathrm{CHOI}^{1}$, Soo Im $\mathrm{CHOI}^{2}$, and Noriko SATO \\ Laboratory of Forest Policy, Division of Forest Environment and Management Sciences, \\ Department of Forest and Forest Products Sciences, Faculty of Agriculture, \\ Kyushu University, Fukuoka 812-8581, Japan \\ (Received June 27, 2008 and accepted July 16, 2008)
}

\begin{abstract}
The objectives of this study were to analyze the situation and problems of promoting the business of the non-national forest in Jeonbuk Province, and to activate the non-national forest management for the improvement of its income. To understand the current status of the non-national forest, data was surveyed and analyzed from 14 cities and counties in the Jeonbuk Province. In result, one of the reasons for stagnant non-national forest management is that there was no security of commercial succession in the non-national forest. The key to successful non-national management is a proper understanding of public interest of the worth of forests and the new strategy of non-national forests as a tertiary industry because economic management of the forest is difficult in the current situation. In addition, investment of non-timber products and launching the supports of non-national forests are required from the local government since the shortterm forest products have a high possibility of success as strategic sources of high income. Jeonbuk Province has to adopt the business items suitable to the actual circumstances and the methods that can promote management of the non-national forest.
\end{abstract}

\section{INTRODUCTION}

The development-oriented policies under the economic system of capitalist markets have made market functions quite successful, but these policies have seriously destroyed our environment. Most of the latest issues such as global warming, carbon discharge rights, and sustainable forest management commonly focus on how to conserve our environment. Moreover, the importance of forestry and reason of existence are to effectively remove the environmental, social and cultural inverse functions in the area of economic development.

One of the most important issues in the forest area from the environmental problems we currently face is how to administer and manage the forest which is highly capable of carbon absorption. The reason being is that the forest is very important as a source of supplying a large quantity of oxygen that must exist to maintain the natural ecosystem such as climatic change, air purification and living organisms (Gene and Frederick, 1986).

Looking at the latest forest related trend, it tends to be focused on the sustainable forest management. This shows that the forest not only becomes an alternative that can solve environmental problems, but is pursued for diversified business operations rather than its management of direct use.

Accordingly, the forest has become a subject of interest internationally and its value appreciates.

In the case of Korea, about $64.1 \%$ of the entire land is forested, but the volume stays at a level that is half that of the advanced countries with $82.3 \mathrm{~m}^{3} / \mathrm{ha}$. The production amount of forest products was about 3.16 trillion

\footnotetext{
Faculty of Forest Science, Chonbuk National University, Chonju, 561-756, Korea

Korea Forest Research Institute, Seoul, 130-712, Korea

* Corresponding author (E-mail: leesh@chonbuk.ac.kr)
}

KRW that is merely $0.4 \%$ of the GNP (Korea Forest Service, 2007). Although restoration of the devastated regions has been quite successful due to the mountain tree-planting policy for past 30 years, the forest area has gradually decreased since 1961 due to the land development-oriented growth.

Moreover, the private forest that takes up 68.9\% (4.4 million ha) of the entire forest becomes an obstruction of forest management since they merely focus on their wealth accumulation, security of burial grounds and speculative motivation. More serious is that ownership is gradually shifting to the non-resident forest owners from the resident forest owners residing within the area (Kim, 1999). This proves that the private forest owners are not interested in forest management since forestry has limitations in the perspective of market functions. Consequently, it is difficult to expect that forestry management will take place without government support and policy involvement.

However, forest management does not have direct results and also, public forest management is left alone due to the lack of local government finances and will. This is because forestry activities are stagnant due to the worsened profitability of forest management from a rise of management costs such as long-term stagnation of forest trees and labor costs and the small-sized business operation as well as the characteristics of forestry such as the large initial investment, long-term investment and uncertainty (Jang et al., 2000). The management of the non-national forest under these hard facts has fallen further behind and the studies on forest management have gradually decreased.

However, the forest holds its meaning of existence for public life as well as for the local and social perspectives of contributing to community development, such as providing a stable supply of wood, promoting land conservation, supporting public health and recreation, and 
protecting the security of water resources. These values for the existence of the forest are further emphasized due to increased environmental problems throughout the world and the need for balanced regional development.

Under these social and economic changes, it is essential to reestablish the value of forest, to increase income, and to understand the importance of environmental-friendly forest management. Therefore, this study was conducted to understand the management and current situation of the non-national forest that consists of about $80 \%$ of the entire forest area in Jeonbuk Province, to understand the components for the activation of forest management, and to provide information for the reasonable management of the nonnational forest.

\section{MATERIALS AND METHOD}

\section{Data collection}

To understand the current status of the non-national forest in Jeonbuk Province, data was surveyed and analyzed from Korea Forest Service, Forest Administration Department of Jeonbuk Province, and Jeonbuk Branch of National Forestry Cooperatives Federation. The survey was carried out in 14 cities and counties in Jeonbuk Province from October 2003 to October 2004 for the $1^{\text {st }}$ survey and the $2^{\text {nd }}$ survey was conducted in 2007. For the forest resource investigation of the objective areas, we based it on the forest resource survey report published by Korea Forest Research Institute and have used the statistical information service of Jeonbuk for forestry related businesses.

To comprehend the actual conditions of non-national forest management, data was collected and analyzed in relation to the forest ownership of Jeonbuk Province, the forest area by the age class of the non-national forest, the current situation of public forest in Jeonbuk Province, the resident and non-resident owners of private forest, and the number of sincere forest managers.

To observe the income improvements through forestry, data collected along with the output of forest products, forestation and erosion control projects for the past 7 years (2000 2006) was used and analyzed. Also, to understand environmental-friendly forest management, we surveyed and analyzed the projects that directly or indirectly influenced the management of the nonnational forest by the development year of the recrea- tional forest and the number of yearly users within the non-national forest of Jeonbuk Province.

\section{Analysis method}

Dynamic analysis

To apprehend the income improvements of forestry, dynamic analysis was performed on the data for the past 7 years (2000 2006) through the time series data of forest products, forestation and erosion control projects. The dynamic analysis, as a statistical index based on time series, can be classified by the variation in single/ multiple statistics, variation between statistics in distribution, and variation of the statistical value groups in a time series.

\section{Estimate model according to number of users}

The recreational forest operated by the non-national sector that fast grows as a public function and service industry was set to the development directions, and users were estimated to predict demand of the visitors to the recreational forest. This study has drawn the quantitative variations of users through the visitor data of recreational forests within the non-national forest of Jeonbuk Province while basing findings on the marginal model of Gompertz. This model, a technique of predicting the number of users in the future while based on the variation characteristics of time series in estimating the number of users, tries to estimate the number of users by setting the upper limit of user increase in the future.

The general form of the marginal model of Gompertz transformed to linear form is expressed as in the following.

$$
\mathrm{P}_{\mathrm{t}}=\mathrm{a}+\mathrm{b}_{\mathrm{t}}
$$

Where, $P$ refers to the number of users at the $t$ year and $\mathrm{a}, \mathrm{b}$ are the coefficients of the variable $\mathrm{t}$.

\section{RESULTS AND DISCUSSIONS}

\section{Forest situation of Jeonbuk Province}

Forest situation of Jeonbuk Province by ownership

The forest situation by ownership of the total forest area of 449,152 ha in Jeonbuk Province, as shown in Table 1, is made up respectively by the national forest of 85,852 ha (19.2\%), public forest of 28,842 ha (6.4\%) and the private forest of 334,458 ha $(74.4 \%)$. As compared to the ratio of country-wide average, $68.9 \%$ by private ownership, the ratio of private forest in Jeonbuk Province has appeared relatively high. Also as for the

Table 1. Forest land areas and growing stock by possession in Jeonbuk Province

Unit: ha, $\mathrm{m}^{3}$

\begin{tabular}{ccrrrr}
\hline Classification & $\begin{array}{c}\text { Forest land areas } \\
\text { (ha) }\end{array}$ & $\begin{array}{c}\text { Growing stock } \\
\left(\mathrm{m}^{3}\right)\end{array}$ & $\begin{array}{c}\text { Growing stock } \\
\left(\mathrm{m}^{3} / \mathrm{ha}\right)\end{array}$ & 86.03 \\
Total & 449,152 & 100 & $38,639,153$ & 100 \\
National forest & 85,852 & 19.2 & $8,238,662$ & 21.3 & 6.4 \\
Pubic forest & 28,842 & 6.4 & $2,483,532$ & 72.3 \\
Private forest & 334,458 & 74.4 & $27,916,959$ & 86.11 \\
\hline
\end{tabular}

Source: Korea Forest Service. 2007 Statistical yearbook of forestry. 
average volumes per hectare $\left(\mathrm{m}^{3} / \mathrm{ha}\right)$, the volumes average of Jeonbuk Province with the national forest of $95.96 \mathrm{~m}^{3}$, public forest of $86.11 \mathrm{~m}^{3}$ and private forest of $83.47 \mathrm{~m}^{3}$ is relatively high in comparison to the national average of $82.30 \mathrm{~m}^{3}$.

Situation of the non-national forest

Looking at the area of the non-national forest by the age class, the age class I of the forest area is comprised of the public forest of 841 ha and private forest of 27,200 ha from the entire forest area of 28,041 ha. And the age class II-V of the forest area is comprised of the public forest of 27,312 ha and private forest of 296,466 ha from the entire forest area of 323,778 ha. Additionally, the age class VI includes the public forest of 155 ha and private forest of 2,141 ha from the entire forest area of 2,296 ha.

Particularly since most forest trees stay at the age level of 30 40 years, they are at the level needed for active tending operations considering the growth characteristics of forest trees. In particular since about 75\% of the private forest is comprised of forest trees at the age class III-IV, expansion of forest roads and facilities and increase of forest tending projects are highly required to keep in step with the age of sustainable forest management (Table 2).

The entire area of public forest from the non-national forest of Jeonbuk Province is 28,842 ha as shown in
Table 3, respectively with 10,636 ha of provincial forest and 18,206 ha of county forest. The region that takes up the largest area is Jinan County, holding the public forest area of 6,506 ha respectively with the provincial forest of 3,665 ha and county forest of 2,841 ha. Contrarily, the region of taking up the smallest forest area is Jeonju City with the public forest area of 71 ha respectively with the provincial forest of $36 \mathrm{ha}$ and city forest of 35 ha.

Since the public forest is mostly distributed in the regions of Wanju (5,556 ha), Jinan (6,506 ha), Muju (3,922 ha), Jangsu (5,054 ha), Imsil (2,412 ha), Namwon (1,800 ha), and Sunchang (1,107 ha), it is required to associate management of the public forest distributed among these regions. This is because management of separated forests is burdensome, and apportioning regionally is the starting point of reasonable management by grouping and forming a large complex of forest areas. Therefore, the grouping project of the public forest is urgent to set a model for private forest management, which has been the existence of the public forest.

One of the greatest problems of private forest ownership in the non-national forest of Jeonbuk Province is that most of them are non-resident and their purpose of forest ownership comes from the desire for wealth accumulation, security of burial grounds and speculative motivation. The fact that a commercial purpose for forestry is not guaranteed becomes a factor that further

Table 2. Forest land areas of non-national forest by age class

Unit: ha

\begin{tabular}{|c|c|c|c|c|c|c|c|c|c|}
\hline & assificat & & Total & I & II & III & IV & $\mathrm{V}$ & VI \\
\hline \multirow{5}{*}{$\begin{array}{c}\text { Non- } \\
\text { national } \\
\text { Forest }\end{array}$} & \multicolumn{2}{|r|}{ Grand total } & 354,115 & 28,041 & 33,614 & 136,854 & 138,288 & 15,022 & 2,296 \\
\hline & \multirow{3}{*}{$\begin{array}{l}\text { Public } \\
\text { forest }\end{array}$} & Total & 28,308 & 841 & 1,350 & 12,078 & 11,552 & 2,332 & 155 \\
\hline & & Provincial forest & 10,384 & 135 & 357 & 4,487 & 4,312 & 1,093 & - \\
\hline & & County forest & 17,924 & 706 & 993 & 7,591 & 7,240 & 1,239 & 155 \\
\hline & \multicolumn{2}{|c|}{ Private forest } & 325,807 & 27,200 & 32,264 & 124,776 & 126,736 & 12,690 & 2,141 \\
\hline
\end{tabular}

Note: Over age class VII is excluded.

Source: Korea Forest Service. 2007 Statistical yearbook of forestry.

Table 3. Public forest land areas by city and county

\begin{tabular}{|c|c|c|c|c|c|}
\hline Classification & Sub-total & Provincial forest & $\%$ & County forest & $\%$ \\
\hline Total & 28,842 & 10,636 & 100 & 18,206 & 100 \\
\hline Jeonju & 71 & 36 & 0.3 & 35 & 0.2 \\
\hline Kunsan & 239 & 1 & 0.01 & 238 & 1.3 \\
\hline Iksan & 179 & 3 & 0.03 & 176 & 1.0 \\
\hline Jeongeup & 499 & 219 & 2.1 & 280 & 1.5 \\
\hline Namwon & 1,800 & 98 & 1 & 1,702 & 9.4 \\
\hline Kimje & 107 & 1 & 0.01 & 106 & 0.6 \\
\hline Wanju & 5,556 & 4,230 & 39.8 & 1,326 & 7.3 \\
\hline Jinan & 6,506 & 3,665 & 34.5 & 2,841 & 15.7 \\
\hline Muzu & 3,922 & 375 & 3.5 & 3,547 & 19.4 \\
\hline Jangsu & 5,054 & 1,001 & 9.4 & 4,053 & 22.2 \\
\hline Imsil & 2,412 & 888 & 8.3 & 1,524 & 8.4 \\
\hline Sunchang & 1,107 & 118 & 1.1 & 989 & 5.4 \\
\hline Gochang & 157 & - & - & 157 & 0.9 \\
\hline Buan & 1,233 & 1 & 0.01 & 1,232 & 6.8 \\
\hline
\end{tabular}

Source: Korea Forest Service. 2007 Statistical yearbook of forestry. 
alienates forest owners from forest management.

Looking at the current situation of resident and nonresident forest owners in Korea, the total number of forest owners as shown in Table 4 is 2,229,522 people and of this number, the Jeonbuk Province makes up about $8.9 \%$ with a total of 199,299 people. Nation-wide, the resident forest owners are 1,183,941 people (53\%) and the non-resident forest owners are 1,045,581 (47\%) people. The resident forest owners in Jeonbuk Province are 128,112 people (64\%) and the non-resident forest owners are 71,187 people (36\%).

The entire area of private forest in Jeonbuk Province totals 334,458 ha with a resident ownership area of $205,523 \mathrm{ha}$ and non-resident ownership area of 128,945 ha. This shows that the resident forest owners hold possession of about 1.6 ha per person and the nonresident owners hold possession of about 1.8 ha per person. Considering that an area of 100 ha or more is needed to manage the forest reasonably, the forest ownership scale of Jeonbuk Province is very small.

On the other hand, the number of sincere forest managers at of the end of 2006 was 387 persons and the number gradually increases. Sincere forest managers can be largely divided into four types such as model, excellent, self-supporting and corporate managers. Looking at Table 5 , the entire number of sincere forest managers throughout the nation was 387 persons; of this number, there were 34 model forest managers, 91 excellent forest managers, 249 self-supporting forest managers and 13 corporate forest managers.

Of this figure, the total number of sincere forest managers in the Jeonbuk area was 53 people; of these, there were 1 model forest manager, 8 excellent forest managers, 42 self-supporting forest managers and 2 corporate managers. The number of forestry successors was 1,805 people in the nation; of these, the number of forestry successors in Jeonbuk Province was 239 people. Looking at the statistical data above, Jeonbuk Province may have much difficulty in achieving reasonable forest management since the number of sincere forest managers and forestry successors who can take a lead in forest management is relatively small.

Amount of forest products

Looking at the amount of forest products in Jeonbuk Province for the recent 7 years (2000 2006), the amount of forest products is classified either by increasing or decreasing as shown in Table 6 . While the products such as woods, fuels, nuts, mushrooms, medicinal plants and wild edible vegetables have increased, the products such as fiber materials, resins and bamboo shoots have decreased. Fiber materials and resins have almost disappeared as they have almost no value.

Figures 1-2 show the changes in the amount of forest products that have been produced in Jeonbuk Province for the recent 7 years (2000 2006). While the amount of wood production has gradually increased, most of the wood consumed each year is imported from foreign countries. Although this can be attributed to the lack of matured stands capable of wood production, the reason being may be that production increase is highly limited due to financial issues. Therefore, it is desirable to increase the production volume within the scope so that the amount of production can contribute to promoting the competitive power of the domestic wood processing industry and to the stability of wood supply. The production volume of mushrooms such as pine and pyogo mushrooms continuously increases (Figure 1).

The reason that the fuel production as shown in Figure 1 has increased in the recent years is because the price competitiveness of domestic wood has improved as

Table 4. Status of resident and absentee forest owners in Jeonbuk Province

Unit: persons, ha

\begin{tabular}{|c|c|c|c|c|c|c|c|c|c|c|c|c|}
\hline \multirow{3}{*}{$\begin{array}{l}\text { Classi- } \\
\text { fication }\end{array}$} & \multicolumn{6}{|c|}{ Forest owners } & \multicolumn{6}{|c|}{ Areas } \\
\hline & \multicolumn{2}{|c|}{ Total } & \multicolumn{2}{|c|}{$\begin{array}{c}\text { Resident } \\
\text { forest owner }\end{array}$} & \multicolumn{2}{|c|}{$\begin{array}{c}\text { Absentee } \\
\text { forest owner }\end{array}$} & \multicolumn{2}{|l|}{ Total } & \multicolumn{2}{|c|}{$\begin{array}{c}\text { Resident } \\
\text { forest owners }\end{array}$} & \multicolumn{2}{|c|}{$\begin{array}{c}\text { Absentee } \\
\text { forest owners }\end{array}$} \\
\hline & $\begin{array}{l}\text { No. of } \\
\text { owners }\end{array}$ & $\%$ & $\begin{array}{l}\text { No. of } \\
\text { owners }\end{array}$ & $\%$ & $\begin{array}{l}\text { No. of } \\
\text { owners }\end{array}$ & $\%$ & Area & $\%$ & Area & $\%$ & Area & $\%$ \\
\hline Total & $2,229,522$ & 100 & $1,183,941$ & 53 & $1,045,581$ & 47 & $4,411,242$ & 100 & $2,188,807$ & 50 & $2,222,435$ & 50 \\
\hline $\begin{array}{l}\text { Jeonbuk } \\
\text { Province }\end{array}$ & 199,299 & 100 & 128,112 & 64 & 71,187 & 36 & 334,458 & 100 & 205,523 & 61 & 128,945 & 39 \\
\hline
\end{tabular}

Source: Korea Forest Service. 2007 Statistical yearbook of forestry.

Table 5. Sincere forest managers and forestry successors in Jeonbuk Province

Unit: persons

\begin{tabular}{|c|c|c|c|c|c|c|c|}
\hline \multirow[b]{2}{*}{ Classification } & \multirow{2}{*}{$\begin{array}{l}\text { Grand } \\
\text { Total }\end{array}$} & \multicolumn{5}{|c|}{ Sincere forest manager } & \multirow[b]{2}{*}{ successor } \\
\hline & & $\begin{array}{c}\text { Total } \\
\text { manager }\end{array}$ & $\begin{array}{c}\text { Model } \\
\text { manager }\end{array}$ & $\begin{array}{l}\text { Excellent } \\
\text { manager }\end{array}$ & $\begin{array}{l}\text { Self-supporting } \\
\text { manager }\end{array}$ & $\begin{array}{c}\text { Corporate- } \\
\text { manager }\end{array}$ & \\
\hline Total & 2,192 & 387 & 34 & 91 & 249 & 13 & 1,805 \\
\hline Jeonbuk & 292 & 53 & 1 & 8 & 42 & 2 & 239 \\
\hline
\end{tabular}

Source: Korea Forest Service. 2007 Statistical yearbook of forestry. 
Table 6. Production of forest products in Jeonbuk Province

\begin{tabular}{cccccccccc}
\hline Year & $\begin{array}{c}\text { Timber } \\
\left(\mathrm{m}^{3}\right)\end{array}$ & $\begin{array}{c}\text { Fuel } \\
(\mathrm{M} / \mathrm{T})\end{array}$ & $\begin{array}{c}\text { Nuts \& } \\
\text { fruits } \\
(\mathrm{kg})\end{array}$ & $\begin{array}{c}\text { Mushrooms } \\
(\mathrm{kg})\end{array}$ & $\begin{array}{c}\text { Fiber } \\
(\mathrm{kg})\end{array}$ & $\begin{array}{c}\text { Resin } \\
(\mathrm{kg})\end{array}$ & $\begin{array}{c}\text { Medicinal } \\
\text { plants } \\
(\mathrm{kg})\end{array}$ & $\begin{array}{c}\text { Bamboo } \\
\text { shoots } \\
(\mathrm{kg})\end{array}$ & $\begin{array}{c}\text { Wild } \\
\text { vegetables } \\
(\mathrm{kg})\end{array}$ \\
\hline 2000 & 127,259 & 6,578 & $6,973,776$ & $1,435,785$ & 3,500 & 23 & 140,481 & 34,791 & $1,120,598$ \\
2001 & 134,563 & 4,236 & $6,609,476$ & $1,322,586$ & 400 & 21 & 261,740 & 22,393 & $1,145,075$ \\
2002 & 159,514 & 2,735 & $6,862,193$ & $1,699,595$ & - & - & 134,308 & 23,907 & $1,065,208$ \\
2003 & 185,897 & 1,371 & $7,110,699$ & $2,341,887$ & - & - & 380,716 & 26,424 & $1,124,440$ \\
2004 & 235,323 & 4,651 & $8,325,810$ & $1,713,282$ & - & - & 342,325 & 20,079 & $1,032,238$ \\
2005 & 303,456 & 7,719 & $11,441,867$ & $1,803,324$ & - & - & 527,706 & 20,815 & $1,448,304$ \\
2006 & 228,897 & 36,475 & $14,374,040$ & $1,917,495$ & - & - & 449,241 & 14,543 & $1,596,586$ \\
\hline
\end{tabular}

Notes: 1) Nuts \& fruits: Chestnut, Walnut, Pine nut, Jujube, Acorn, Gingko nut, others.

2) Mushroom: Pine mushroom, pyogo mushroom, Black Fungus, Oyster mushroom, others.

3) Medicinal plants: medical plant, Cornelian cherry fruit, others.

Source: Forestry administrative division in Jeonbuk Province.
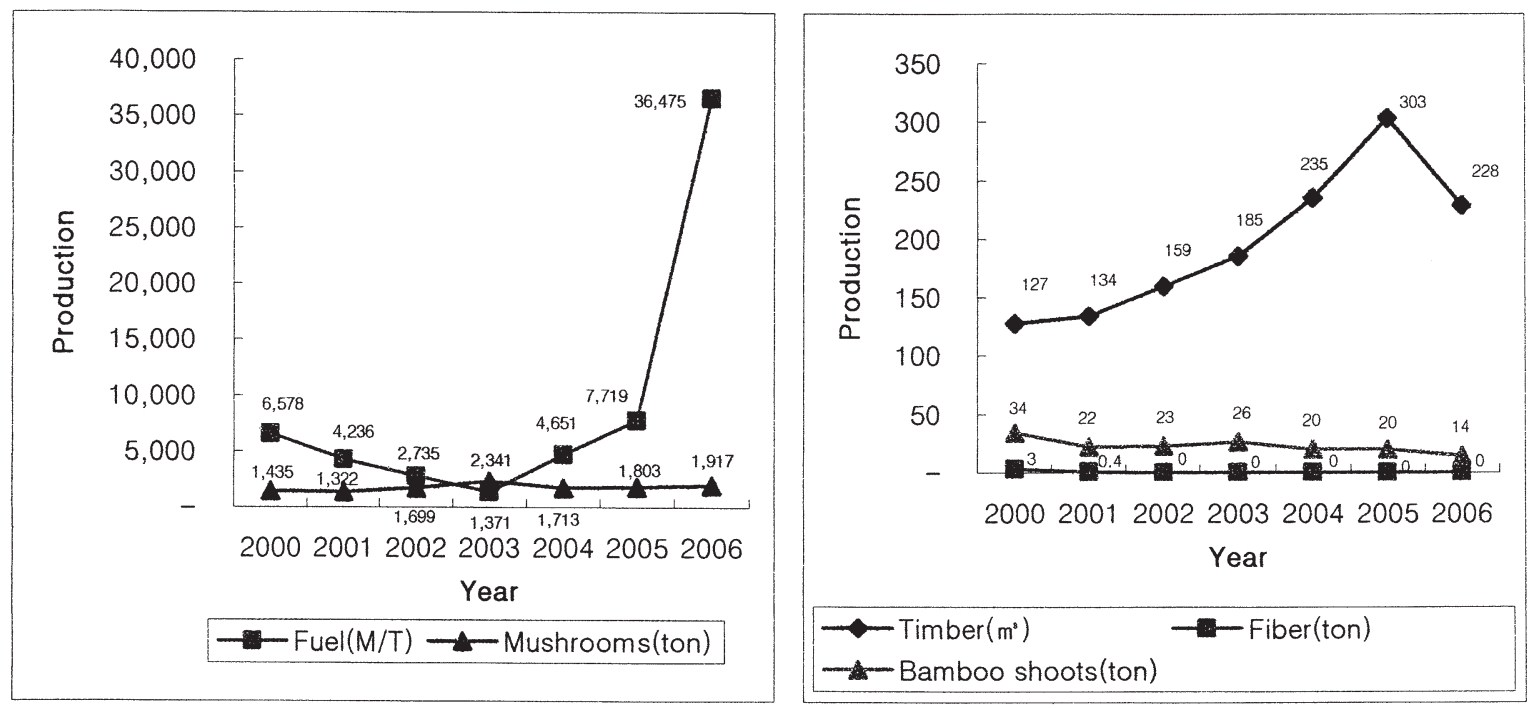

Fig. 1. Production of fuel, mushrooms, timber, fiber, and bamboo shoots.
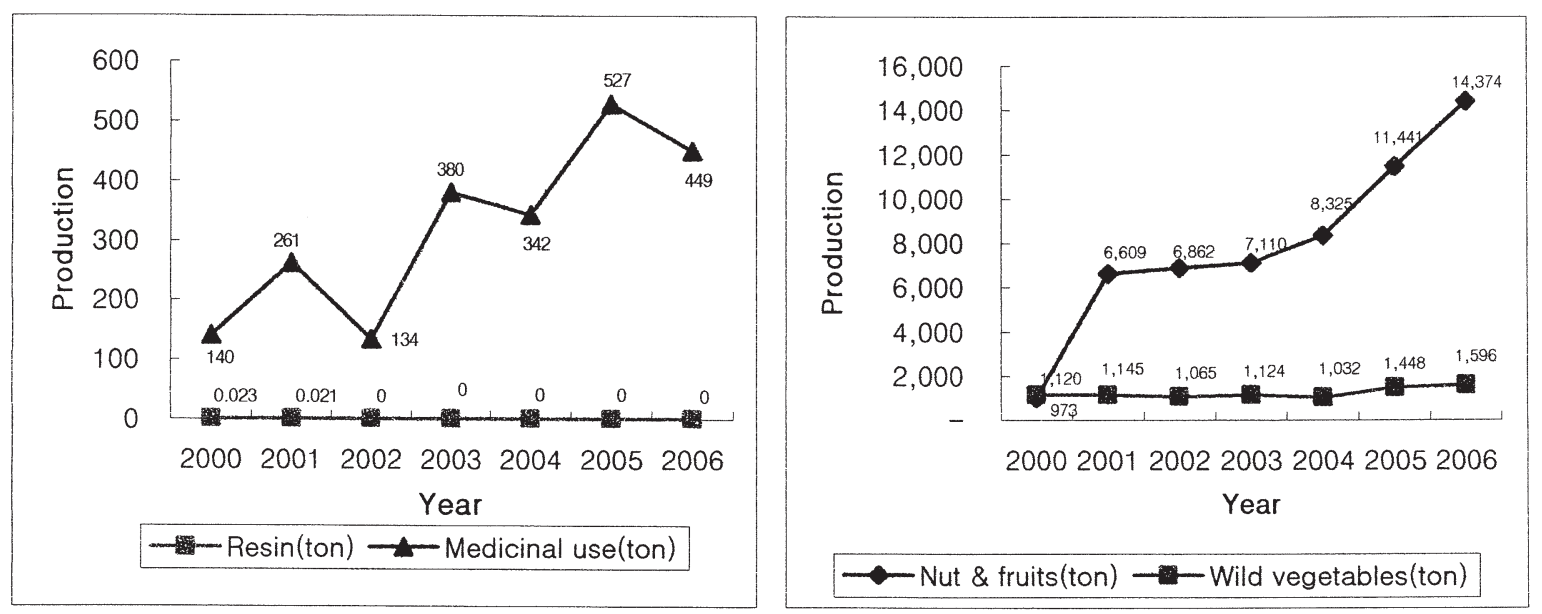

Fig. 2. Production of resin, medicinal plants, nuts and fruits, and wild vegetables.

compared to the price increase of imported wood from a sudden rise of marine transportation costs since the year 2003. The production of bamboo shoots has decreased from $34,791 \mathrm{~kg}$ in 2000 to $14,543 \mathrm{~kg}$ in 2006 , and the production volume of fiber materials has not been noticeable since the year 2002 .

As health awareness increases along with the population, preferences to medicinal plants have consistently increased. As if this tendency is reflected, the production volume of medicinal plants in the Jeonbuk Province 
area has consistently increased as shown in the Figure 2. The main factors that increase and decrease may be attributable to a reduction in natural production and the increase of medicinal plants imported from China, the main country of import.

The production of nuts such as chestnut, walnut, pine nut and gingko nut has greatly increased from $6,973,776 \mathrm{~kg}$ in 2000 to $14,374,040 \mathrm{~kg}$ in 2006 . The production of wild edible vegetables has apparently shown an increase from $1,120,598 \mathrm{~kg}$ in 2000 to $1,596,586 \mathrm{~kg}$ in 2006 (Figure 2). However, since the production base and competitive power are weak, most are overwhelmed by a large volume of cheap forest products from China. To overcome this situation, we need to build a management mind and system that can quickly respond to market changes and to create a network and efficient information exchange system for managers.

Since most of non-national forests in Jeonbuk Province are comprised of the trees with the age class III-IV, forest managers may not secure a stable income in the short term. However, as the demand for forest products within the forest increases continuously from the improvements of living standards in recent days, support from Jeonbuk Province and local governments is highly in need.
The positive support of the local government for short-term forest products may encourage forest management. An intensive investment strategy is required for these short-term forest products to promote management of the non-national forests since the short-term forest products have a high probability of success as a strategic high income source.

\section{Forestation in the non-national forest}

The forestation area by ownership at the end of 2006 within the non-national forest of Jeonbuk Province totaled 3,164 ha, and the number of trees were 8,102,000 trees. Of these, the area of private forest makes up about 98\% with 3,087 ha (8,017,000 trees). Jeonbuk Province, to prevent the rapid temperature increase of recent days, urban heat island due to the rapid growth of urban area and urban green-house effect, plants many trees in urban areas, on tree-lined streets and in forest areas. Also as the campaign of removing walls in the government and public offices and schools in the urban area becomes a trend focus has been given to planting trees appropriate to local characteristics.

As shown in Table 7 and Figure 3, the forestation of Jeonbuk Province can be characterized by the increase of coniferous trees and broad-leaved trees. In particular,

Table 7. Reforestation in Jeonbuk Province

Unit: ha, 1,000 seedings

\begin{tabular}{|c|c|c|c|c|c|c|c|c|c|c|}
\hline \multirow{2}{*}{ Year } & \multicolumn{2}{|c|}{ Conifers } & \multicolumn{2}{|c|}{ Non-Conifers } & \multicolumn{2}{|c|}{ Nut \& fruit spp } & \multicolumn{2}{|c|}{ Big seeding } & \multicolumn{2}{|c|}{ Others } \\
\hline & Area & No. of sdls & Area & No. of sdls & Area & No. of sdls & Area & No. of sdls & Area & No. of sdls \\
\hline 2000 & 692 & 1,932 & 558 & 2,063 & 266 & 157 & 194 & 304 & - & - \\
\hline 2001 & 493 & 1,368 & 786 & 2,931 & 215 & 99 & 236 & 356 & - & - \\
\hline 2002 & 199 & 609 & 614 & 3,448 & 237 & 133 & 274 & 294 & - & - \\
\hline 2003 & 611 & 1,420 & 2,237 & 6,607 & 199 & 79 & 121 & 183 & 40 & 20 \\
\hline 2004 & 513 & 1,251 & 1,961 & 4,952 & 141 & 62 & 208 & 374 & 83 & 29 \\
\hline 2005 & 495 & 1,275 & 1,899 & 5,209 & 159 & 77 & 148 & 129 & 15 & 53 \\
\hline 2006 & 778 & 1,993 & 2,386 & 6,109 & 161 & 132 & 405 & 380 & 53 & 55 \\
\hline
\end{tabular}

Source: Forestry administrative division in Jeonbuk Province.

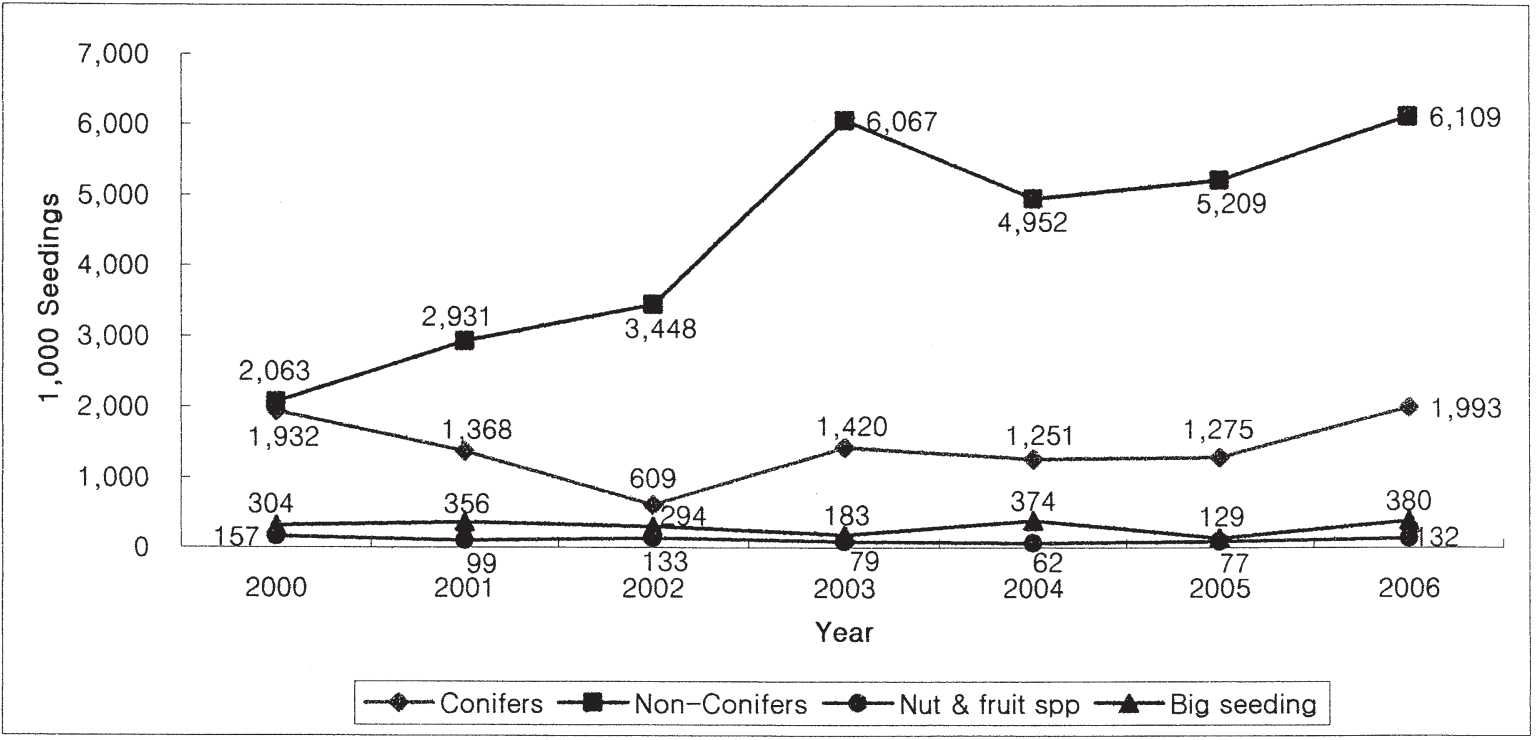

Fig. 3. Reforestation in Jeonbuk Province. 
the forest of broad-leaved trees has increased from $2,063,000$ trees in 2000 to 6,109,000 trees in 2006, increasing the forestation area of 558 ha to 2,386 ha. This result can be interpreted as the groves of broad-leaved trees are used for urban tree-lined streets and urban scenery and also, the ratio of broad-leaved trees tends to increase in order to stabilize the forest ecosystem. Most trees planted in the urban area are large, and this shows that the forestation area and number of trees have increased since the year 2000 .

However, the forestation of the non-national forest holds several problems in spite of these efforts. Firstly, they lack in a sense of sovereignty for the business as a forest owner; in other words, they do not have the will to take care of the forest by themselves. Secondly, the proper forestry can not be accomplished due to the economic scale and difficulty of owners and lack of management technology. Thirdly, the financial support for sincere forest owners by the local government is not sufficient although there is an aid in the perspective of for- estation business. To solve for these problems imminently, it is judged that a lot of change should be made in the policy perspective of forestry promotion.

To solve these problems, selection of the tree species shall be made according to the main body of forestation (private forest, public forest). Profitability shall have priority in selecting the tree species of forestation from the perspective of forest owners since they take the leading role in raising the self-sufficiency of domestic timber. Even the forestation policy corresponding to the management policy of long-term timber supply and forest resources can be avoided if profitability is not guaranteed in the perspective of forest owners. Accordingly, selection of the tree species for forestation shall be determined according to the party of forestation. The policy on the selection of forestation tree species that has uniformly recommended tree species regardless of the main body of forestation should be reestablished to induce voluntary participation of forest owners.

It is essential to increase forestry income innovatively

Table 8. Accomplishment of erosion control in Jeonbuk Province

Unit: ha, 1,000 seedings, 1,000 won, km

\begin{tabular}{|c|c|c|c|c|c|c|c|c|c|c|}
\hline \multirow{2}{*}{ Year } & \multicolumn{3}{|c|}{ Total } & \multicolumn{2}{|c|}{$\begin{array}{c}\text { Coastal } \\
\text { erosion control }\end{array}$} & \multicolumn{3}{|c|}{$\begin{array}{c}\text { Torrent } \\
\text { erosion control }\end{array}$} & \multicolumn{2}{|c|}{$\begin{array}{l}\text { Erosion control } \\
\text { dam sweeping }\end{array}$} \\
\hline & Area & $\begin{array}{l}\text { No. of } \\
\text { sdls }\end{array}$ & $\begin{array}{l}\text { Business } \\
\text { amount }\end{array}$ & Area & $\begin{array}{l}\text { No. of } \\
\text { sdls }\end{array}$ & $\begin{array}{l}\text { Business } \\
\text { amount }\end{array}$ & $\begin{array}{l}\text { Business } \\
\text { amount }\end{array}$ & Extension & Places & $\begin{array}{l}\text { Business } \\
\text { amount }\end{array}$ \\
\hline 2000 & 5.0 & 12.0 & $2,674,095$ & 5.0 & 12.0 & 718,422 & 859,180 & 7.5 & 13 & $1,096,493$ \\
\hline 2001 & 5.0 & 6.0 & $3,846,543$ & 5.0 & 6.0 & 784,227 & $1,456,658$ & 12.0 & 15 & $1,605,658$ \\
\hline 2002 & 8.5 & 2.9 & $3,681,703$ & 8.5 & 2.9 & 550,791 & $1,269,325$ & 13.0 & 14 & $1,861,587$ \\
\hline 2003 & 8.0 & 13.0 & $6,278,013$ & 8.0 & 13.0 & $1,198,232$ & $2,252,857$ & 16.0 & 19 & $2,826,924$ \\
\hline 2004 & 8.6 & 12.3 & $8,405,850$ & 8.6 & 12.3 & $1,071,206$ & $3,135,829$ & 18.0 & 20 & $4,642,612$ \\
\hline 2005 & 9.0 & 20.9 & $7,057,882$ & 9.0 & 20.9 & $1,192,031$ & $1,972,419$ & 11.0 & 18 & $3,893,432$ \\
\hline 2006 & 11.0 & 21.6 & $7,005,884$ & 11.0 & 21.6 & 741,900 & $1,695,550$ & 9.0 & 20 & $4,568,434$ \\
\hline
\end{tabular}

Source: Forestry administrative division in Jeonbuk Province.

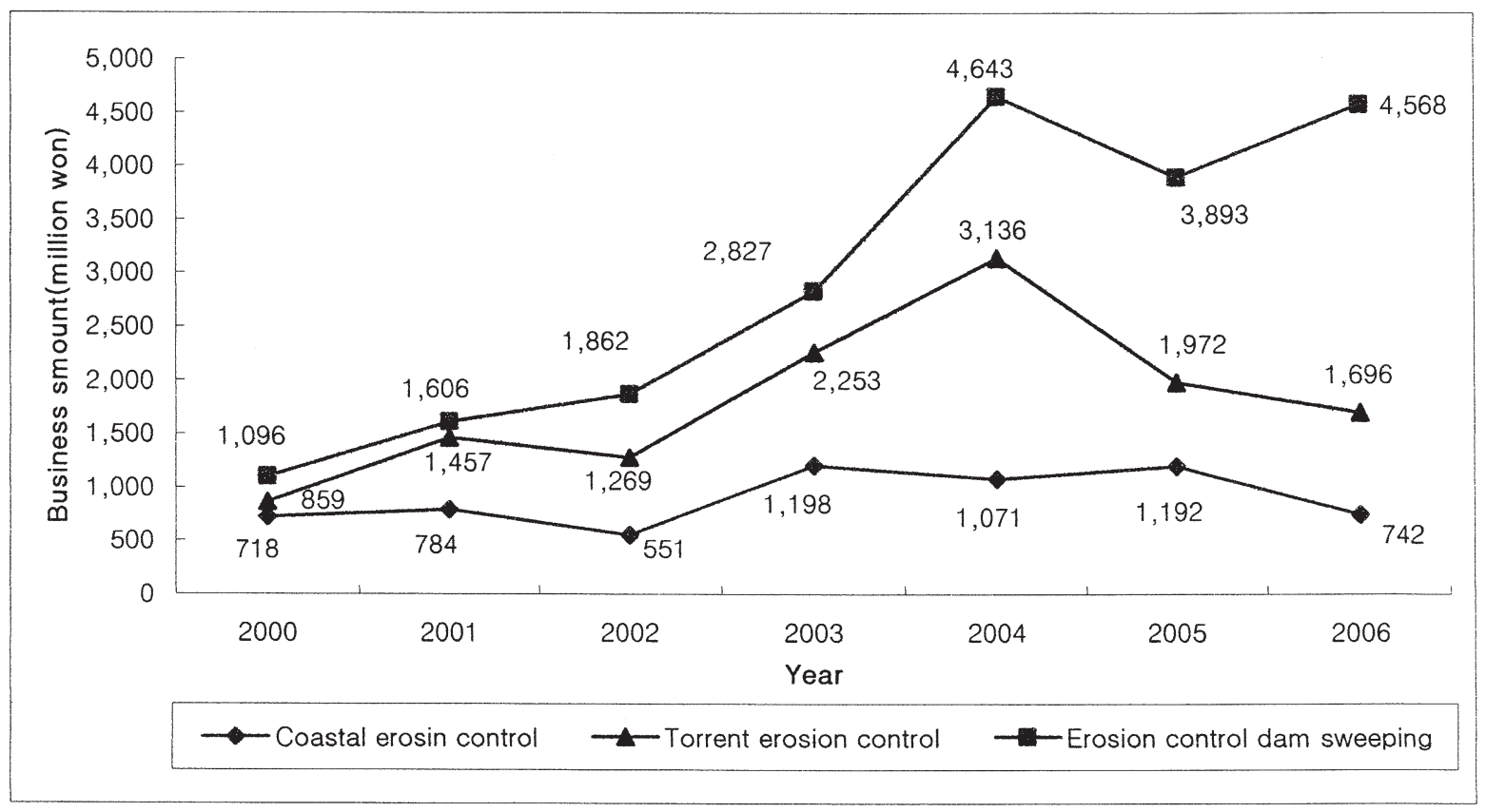

Fig. 4. Amount of erosion control projects in Jeonbuk Province. 
by developing tree species suitable to the forestation environment. The timber self-sufficiency level of 30\% that the Forestry Service has suggested for the forestation vision in the $21^{\text {st }}$ century (Korea Forest Service, 2000) may not be achieved only by foresting the national forest. It is obvious that the promotion of the non-national forest corresponding to $80.8 \%$ of the entire forest area may determine the future of forestry in Jeonbuk Province. Erosion Control project within the non-national Forest

Since the forest in Korea has the young stand, the forest cover is limited. Also, consistent management of forests is necessary due to a lot of torrential streams from geographic features, which sweep soils and sands from hilly countries and raise the number of floods from the rapid flows of rivers when there is a lot of rainfall (Woo, 1997). In the current situation of Jeonbuk Province where the ratio of artificial forest is high, a consistent and appropriate measure of erosion control is urgently needed.

The erosion control project of Jeonbuk Province as shown in Table 8 and Figure 4 has increased from 718,442 thousand KRW in 2000 to 741,900 thousand KRW in 2006 for the construction cost of forest and sand dune fixation, from 859,180 thousand $\mathrm{KRW}$ in 2000 to $1,695,550$ thousand $\mathrm{KRW}$ in 2006 for the construction cost of torrent wild stream erosion control, and from 1,096,493 thousand KRW in 2000 to 4,568,434 thousand KRW in 2006 for the construction cost of debris barrier. The total construction cost of the erosion control project in Jeonbuk Province has increased from 2,674,095 thousand KRW in 2000 to 7,005,884 thousand KRW in 2006 and the number of debris barriers has increased from 13 places in 2000 to 20 places in 2006. This shows the result that the functions of the forest have enhanced not only the economic functions but also public interests.

The effects that have appeared from the result of erosion control within these non-national forests may aid in preventing disasters, developing a source of water supply and preserving the water quality. In particular, Jeonbuk Province may have a large keeping effect of water due to the debris barrier since the lengths of valleys are short and water flows only during the rainy season. Also, erosion control is essential in that the forest damage made by humans gradually increases along with the population and industrial development in providing for the preservation of the living environment. If the ground is damaged, restoration can be quite difficult since the earth and soil can be easily eroded from a small quantity of rainfall until the ground can be stabilized.

Accordingly, the facilities installed in the nonnational forests such as multi-purpose debris barrier, erosion control of community environment and cleanup facility of torrent for water quality have multi-purpose effects such as disaster prevention, water supply, water quality control and residential environment improvement. Hence, they can play the roles of maximizing the public functions of forests by providing various goods and services to residents.
Management of the non-national forest as a tertiary industry

Operation of recreational forest in Jeonbuk Province

Economic management of the forest is difficult in the current situation of Jeonbuk Province. So, the importance of forest management has to be emphasized more as a tertiary industry. As for the operation of recreational forest, the non-national forest has more potential and can provide a good model of creating economic benefits. Forestry in Korea since the 1990s has tried to shift into one of the tertiary industries that is a recreation business in an attempt to get out of the primary industries or secondary industries of material processing, and the Forestry Service has started to promote the recreational forest as an important business since the year 1988 . Therefore, the recreational forests in the Jeonbuk areas were mostly established after the year 1990 .

Jeonbuk Province has developed and operated 9 recreational forests where the natural view is excellent and the places are near urban areas. There are 6 places such as Gosan, Daea, Waryong, Banghwa-Dong, Sesim and Heungbugol in Namwon that recreational forests are owned and operated by local governments in Jeonbuk Province. On the other hand, there are only two places (Seongsusan and Namwon) owned and operated by individuals and 1 place (Banditbul) owned and operated by a local county. The recreational forest with the largest area is the Gosan recreational forest with 673 ha and the smallest is Namwon recreational forest with 32 ha. In particular, the recreational forests of Gosan and Seongsusan are representative in the nation for their respective sizes of 673 ha and 425 ha.

Although the recreational forests owned and operated by local governments have achieved the economic benefits as well as promoted public interests since they are close to urban areas and are naturally beautiful, the economic benefits are quite limited as compared to the initial investments. Even under these difficult situations, the financial situation of the Gosan recreational forest close to the urban area is improving, gradually making profits as it has an annual average of 50,000 visitors since its opening and the recreational forests in SeongsuDong, Waryong and Namwon have an annual average of 10,000 visitors.

As shown in Table 9, the total number of recreational forest visitors in Jeonbuk Province has increased from 102,000 people in 2000 to 168,079 people in 2006 . The reason that the increasing trend of recreational forest visitors dropped both in 2002 and 2004 is because the recreational forests as well as various convenient facilities were damaged from sweepings and landslides due to the typhoons Rusa and Maemi. Therefore, it is necessary to take the appropriate measures suitable to the demand by predicting the number of recreational forest visitors rather than simply using the statistics of recreational forest visitors and to use this data for the reasonable operation of recreational forests.

Estimation of recreational forest users

The detailed plan such as facility size and investment time can not be established without quantitative 
Table 9. Number of visitors to recreational forests in Jeonbuk Province

Unit: persons

\begin{tabular}{|c|c|c|c|c|c|c|c|}
\hline Classification & 2000 & 2001 & 2002 & 2003 & 2004 & 2005 & 2006 \\
\hline Daea & - & - & - & - & - & - & - \\
\hline Seong-susan & 21,662 & 24,145 & 10,631 & 19,964 & 20,111 & 19,319 & 21,500 \\
\hline Waryong & 20,189 & 23,298 & 21,754 & 22,977 & 22,165 & 13,816 & 15,202 \\
\hline Namwon & - & - & 1,585 & 9,645 & 20,379 & 30,364 & 28,584 \\
\hline Sesim & 4,968 & 4,865 & 2,058 & 2,992 & 3,705 & 1,454 & 2,050 \\
\hline Namwon-Hungbugol & - & - & 2,509 & 78,050 & 3,480 & 4,078 & 4,162 \\
\hline Gosan & 55,181 & 76,023 & 71,599 & - & 73,970 & 83,665 & 92,605 \\
\hline Banghwadong & - & - & - & 21,059 & 4,047 & 3,476 & 3,976 \\
\hline Total & 102,000 & 128,331 & 110,136 & 157,366 & 147,857 & 156,172 & 168,079 \\
\hline
\end{tabular}

Source: Korea Forest Service. 2007 Statistical yearbook of forestry.

estimation and dynamic analysis. Accordingly, before drafting a more detailed and practical plan, the estimation of visitors in the corresponding area shall be preceded (Won, 1996). This study has drawn the quantitative variations of users through the visitor data of recreational forests within the non-national forest of Jeonbuk Province while basing findings on the marginal model of Gompertz. This model, as a technique of predicting the number of users in the future while based on the variation characteristics of time series in estimating the number of users, tries to estimate the number of users by setting the upper limit of user increase in the future. The number of recreational forest users in the Jeonbuk areas has greatly increased from 57,704 people in 1995 to 168,079 people in 2006 (Table 10). To establish a reasonable management policy of recreational forests by using these statistics, it is necessary to estimate the demand for the recreational forest in the future.

A change in the trend of the number of recreational forest users can be calculated from the linear regression analysis model as in the following.

$$
\mathrm{P}_{\mathrm{t}}=\mathrm{a}+\mathrm{b}_{\mathrm{t}}
$$

Table 10. Visitors trend to recreational forests in Jeonbuk Province Unit: persons

\begin{tabular}{rrrr}
\hline Year & Population & Year & Population \\
\hline 1995 & 57,704 & 2001 & 128,331 \\
1996 & 130,366 & 2002 & 110,136 \\
1997 & 109,265 & 2003 & 157,336 \\
1998 & 73,076 & 2004 & 147,857 \\
1999 & 116,490 & 2005 & 156,172 \\
2000 & 102,000 & 2006 & 168,079 \\
\hline
\end{tabular}

Source: Korea Forest Service. 2007 Statistical yearbook of forestry.

Table 11. Estimation of visitors to recreation forests in the future Unit: persons

\begin{tabular}{cccc}
\hline Year & Population & Year & Population \\
\hline 2009 & 215,582 & 2014 & 271,992 \\
2010 & 226,864 & 2015 & 283,274 \\
2011 & 238,146 & 2016 & 294,556 \\
2012 & 249,428 & 2017 & 305,838 \\
2013 & 260,710 & 2018 & 317,120
\end{tabular}

Where, $\mathrm{P}$ refers to the number of users at the $\mathrm{t}$ year and $\mathrm{a}, \mathrm{b}$ are the coefficients of the variable $\mathrm{t}$. Calculating the parameter values of linear regression equation, $\mathrm{a}=1224$ and $\mathrm{b}=11281$ could be obtained.

Accordingly, the following expression can be obtained.

$$
\mathrm{P}_{\mathrm{t}}=1,224+11,282_{\mathrm{t}}
$$

Estimating the number of users in the future from the year 2009 by using the function (2) yielded the result as shown in Table 11.

When the number of recreational forest visitors drastically changes due to an external factor, it may not be practical to estimate the number of visitors in the long term of 20 years or more. Therefore, the number of recreational forest users for 10 years from 2009 to 2018 was estimated. According to the estimated result of recreational forest users within the non-national forests of Jeonbuk Province using the marginal model of Gompertz, the number of users will continuously increase from 215,582 people in 2009 to 317,120 people in 10 years.

Assuming that the number of recreational forest visitors keeps increasing, development of a reasonable way of managing recreational forests will be needed while considering use of recreational resources for future generations. In other words, the recreational forests within the non-national forest should be consistently supported and managed so that people can resolve stress and spend time in the nature in accordance with its original purpose. Also, the public functions of non-national forests should be extended by developing an efficient policy with various programs that could be provided to users in connection with the forest life experience, history, culture and education.

\section{CONCLUSION}

To promote use of the non-national forest, a more practical management strategy is essential in solving the financial difficulty of forest owners and their small ownership structure. To overcome these problems, Jeonbuk Province has to adopt the business items suitable to the actual circumstances. The methods that can promote management of non-national forests are followed as below. 
Firstly, we need to maximize use of the forest from the perspective of benefit to the public. Recently, as the forest becomes an important issue in resolving environmental problems, interest and awareness for the public functions of the forest have greatly increased. The public functions of the forest can be achieved when we manage it actively rather than letting it merely exist. In other words, the goal of non-national forest management is to improve the healthy state of the forest and to consistently secure the public functions of the forest through various erosion control projects.

Secondly, an intensive investment shall be made in developing short-term forest products. The proportion of short-term forest products of the total production amount of forestry in 2006 has reached to about 30\%. Therefore, the income improvement of short-term forest products may help promote management of the forest that has been left alone from disinterest in management will.

Thirdly, to activate forestation business, grouped timber production forest should be secured and selection of tree species should vary according to the subject of forestation. Forestry within the non-national forest has not been appropriately made due to lack of owners' will, pettiness, lack of management technology, and insufficient local government support. To solve these problems, 1 2 strategic tree species should be selected and the collectivized and sized timber production forest should be secured. Also, tree species high in profitability and short in rotation time of harvesting timber should be recommended.
Finally, the non-national forests should be developed as tertiary industries. Since the purpose of forest management is of public benefit, it will be effective to put more weight on the tertiary industries under the situation that most of the forests in Jeonbuk Province are at the age class III-IV. Currently, the recreational forests within the non-national forests of Jeonbuk Province have not been reasonably operated since they have neither introduced a concept of service marketing nor predicted demand in the future. Accordingly, they have to be consistently managed while considering the systematic management programs and promotion measures based on the demand suggested and predicted in this study and at the same time, should be developed as places of education that can nurture the ecological sensitivity and imagination of people.

\section{REFERENCES}

Gene, W and J. D. Frederick. 1986 Urban forestry. John Wiley and Sons. New York

Jang, C. S., Y. S. Hwang and Y. L. Kim. 2000 The SOC investment and direction of policy improvement in forest area. Korea Rural Economic Institute

Kim, N. K. 1999 A plan of reformation of Forestry Cooperative Federation. A note of discussion about improvement direction of Forestry Cooperative Federation

Korea Forest Service. 2000 The 21st Century Forest Vision

Korea Forest Service. 2007 Statistical yearbook of forestry

Won, J. M. 1996 Technique of policy analysis. Parkyoungsa, Korea

Woo, B. M. 1997 Erosion control engineering. Hyangmoonsa, Korea 